\title{
Phytoprotection
}

\section{Fungal Disease Control in Banana, a Tropical Monocot : Transgenic Plants in the Third World?}

\section{László Sági, Serge Remy et Rony Swennen}

Volume 79, numéro 4, 1998

OECD Workshop - Sustainable Pest Management, Safe Utilization of New Organisms in Biological Control. Montréal, Québec, Canada. September 27-30, 1998.

Atelier de l'OCDE - Gestion durable des ennemis des cultures, Utilisation sécuritaire de nouveaux organismes de lutte biologique. Montréal, Québec, Canada. 27-30 Septembre 1998.

URI : https://id.erudit.org/iderudit/706168ar

DOI : https://doi.org/10.7202/706168ar

Aller au sommaire du numéro

Éditeur(s)

Société de protection des plantes du Québec (SPPQ)l

ISSN

0031-9511 (imprimé)

1710-1603 (numérique)

Découvrir la revue

Citer cet article

Sági, L., Remy, S. \& Swennen, R. (1998). Fungal Disease Control in Banana, a Tropical Monocot : Transgenic Plants in the Third World? Phytoprotection, 79(4), 117-120. https://doi.org/10.7202/706168ar d'utilisation que vous pouvez consulter en ligne. 


\title{
Fungal Disease Control in Banana, a Tropical Monocot: Transgenic Plants in the Third World?
}

\author{
László Sági, Serge Remy, Rony Swennen
}

Laboratory of Tropical Crop Improvement Catholic University of Leuven, Belgium

\section{INTRODUCTION}

In a recent lecture, the plant breeder Norman Borlaug (1970 Nobel Peace Prize Laureate) underlined that plant biotechnology is likely to be instrumental in dealing with the complexities of "feeding a world of 10 billion people" (1) that the current population of 5.8 billion would certainly reach during the next century before stabilizing. Agricultural biotechnology is expected to play a particular role in the less developed countries (LDCs) where still 800 million underfed people are concentrated but where special constraints and challenges are faced with. For example, the population in the Third World relies to a large extent on staple crops as cassava, sweet potato and tropical fruits that are hardly known in the developed countries. As a result, highquality scientific research is scarce with these crops. In addition, the tropical climate that prevails in most LDCs causes a number of significant consequences, e.g. due to the absence of dormancy, (i) many tropical crops propagate (exclusively) vegetatively which makes classical breeding extremely difficult, and (ii) pathogens and pests can permanently damage their hosts.

\section{BANANA: A CASE STORY}

Banana is a very characteristic case to describe the dimensions and problems biotechnological research will meet in the Third World. With more than 85 million metric tons annually produced mainly in backyards and small farms in 120 countries (2), banana is the No. 1 fruit crop in the world which is not only consumed fresh or as dessert but baked, boiled, cooked, fried and even brewed to beer or puréed for baby food. Ninety percent of banana production is consumed locally and serves as staple food for some $\mathbf{4 0 0}$ million people worldwide due to the high starch content. In fact, banana is the fourth major food source (after rice, milk and wheat) in the developing world. In addition, the export value of the $10 \%$ production entering international trade is estimated to US $\$ 3$ billion that generates a significant income for the economy of numerous LDCs. All these facts and figures demonstrate that banana is actually the most important fruit crop on earth.

On the other hand, most cultivated bananas are parthenocarpic landraces that are sterile triploids. This and their relatively long life cycle hinders successful hybridization programs to transfer disease resistance from wild diploid sources. In addition, many landraces become susceptible to several viral, bacterial and fungal pathogens as well as the nematode and insect pests that cause steadily increasing problems in commercial plantations, too. For instance, the annual cost of fungicide sprays against the pathogen of black Sigatoka leaf disease, Mycosphaerella fijiensis, ranges between US\$600 and 1800 per hectare which amounts up to 
$40 \%$ of the total production cost. Such sprayings are carried out almost every week and pose a high pressure to the environment as documented by the frequent reported fish-kills in the neighborhood of banana plantations. Highly toxic nematicides are also heavily used, some of which sterilized 13,000 plantation workers in Costa Rica in the early 1980s. Finally, smallholders and individuals who cannot afford or have access to chemicals have to cope with yield declines of $30 \%$ or more.

While significant basic scientific knowledge is missing in many fields of banana research, important progress has been made recently in other areas (reviewed in ref. 3). For instance, no classical genetic maps are available, cytology and classical cytogenetics has been hardly done, and plant-pathogen interactions have been very poorly characterized as well. On the other hand, banana is one of the most extensively micropropagated species in the world and various advanced in vitro culture techniques have been adapted for the production of regenerable embryogenic cell suspension and protoplast cultures. Based on this progress, foreign genes were introduced into banana protoplasts and the first transgenic plants were produced either by particle bombardment of embryogenic cell suspension cultures or by Agrobacteriummediated transformation of cultured meristems. While, due their sterility, most banana cultivars do not produce seeds under natural conditions and crosses with other cultivars or species will not occur, here this handicap turns out to be an apparent advantage because the introduced transgene(s) remain(s) confined to the cultivar in which it has been introduced. Based on this argument banana can be considered as a low risk species for transgenic field trials as also confirmed by a theoretical model from different viewpoints (4).

\section{FUNGAL DISEASE CONTROL BY GENETIC TRANSFORMATION}

Since the most significant damage as well as future threat to banana production are caused by fungal pathogens, the introduction of genes conferring resistance to these pathogens is a primary research target. Our efforts are presently focused on several genes encoding stable, cysteine-rich antimicrobial peptides (AMPs) which are isolated from seeds of diverse plant species (reviewed in ref. 5). These AMPs have a broad anti-fungal spectrum and show high in vitro activity against field isolates of Mycosphaerella fijiensis and Fusarium oxysporum, the two main fungal pathogens of banana, while they exert no toxicity to human or plant cells. To date, five AMP genes have been introduced in our laboratory alone and in double- or triple combinations into embryogenic cell suspension cultures of banana using particle bombardment. Large-scale molecular and biochemical characterization of the regenerated transgenic lines confirmed that a vast majority contained and expressed the foreign genes. For example, extensive PCR-screening of a total of 776 putative transgenic plants revealed that more than $90 \%$ of them contained the selectable marker gene as well as the AMP genes. Similarly, Southern hybridization of 56 independent transgenic plants demonstrated that $89.3 \%$ had the transgenes integrated in their genome.

To study the expression of antimicrobial peptides in the transgenic plants, some of the AMP genes was placed under the control of three different promoters which had previously been shown to drive high gene expression in banana as well as in other monocots. Using specific antibodies, the concentration of two AMPs in total transgenic leaf protein extracts ranged from $0.05 \%$ to more than $1 \%$ depending on the promoter used. Addition of these leaf extracts to germinating spores and mycelia of a field isolate of Mycosphaerella fijiensis, the causal agent of black Sigatoka leaf disease, resulted in a significant inhibition of fungal growth 
making these plants likely candidates to control this pathogen under field conditions. In addition, screening of 50 independent transgenic lines with a new in situ leaf bioassay allowed us to select and micropropagate lines with improved resistance to several fungal pathogens.

Field tests will demonstrate whether these transgenic plants express the functional AMPs at levels high enough to control fungal leaf or root diseases in nature. It has been shown that one foreign AMP gene is also transcribed in the fruit, opening the opportunity to create resistance against pre- and postharvest diseases such as cigar-end rot and crown rot.

\section{INTRODUCTION OF TRANSGENIC PLANTS TO THIRD WORLD COUNTRIES: CONCERNS AND IMPACTS}

Once transgenic plants have been produced, their further management and field release requires the careful coordination of a large number of factors. For instance, field release must be authorized by national governments through their respective regulatory bodies. According to our experience, field testing in these countries should definitely involve an active breeding program (such as a CGIAR institute) to ensure that plants are evaluated correctly and precise observations are taken. However, in many LDCs operational regulatory bodies are not yet in place, and this causes delays in implementing field testing of transgenic plants. Additional delaying factors in many LDCs and especially in sub-Saharan Africa are: political instability, recent economic recession, lack of trained personnel (scientists, lawyers) devoted to clear confusion and suspicion and decrease bureaucracy.

To date, no transgenic banana plants are being tested in the field. This is essentially due to the lack of functional regulatory bodies as well as to the underlying reasons in the countries where testing would be carried out. In view of the fact that more and more transgenic plants are being produced by laboratories worldwide, the lack of regulatory mechanisms is likely to continue to be a major bottleneck to progress. It is therefore recommended that greater efforts, at both national and international level, be made to resolve this situation.

Finally, in view of the limited resources being devoted to tropical crop research, it is important that donor agencies put emphasis on supporting collaboration between successful breeding institutions and advanced biotechnology laboratories. However, for correct perception of the real situation, it may be interesting to know that the total plant biotechnology-related investment of CGIAR currently amounts to about US\$15 million which is less than what a small biotechnology company spends on R\&D in the United States (6). On the other hand, black Sigatoka resistant bananas alone would produce at least US $\$ 6$ billion added value if cultivated in sub-Saharan Africa only.

\section{REFERENCES}

Borlaug NE (1997) Feeding a world of 10 billion people: the miracle ahead. Website at http:// agriculture.tusk.edu/biotech/monfort2.htm

Anonymous (1997) FAO Production Yearbook 1996. Vol. 50. FAO, Rome

Sági L, May GD, Remy S, Swennen R (1998) Recent developments in biotechnological research on bananas (Musa spp.). In: Biotechnology and Bioengineering Reviews, Vol. 15, pp. 313-327. Intercept Ltd, Andover, UK

Barton J, Crandon J, Kennedy D, Miller H (1997) A model protocol to assess the risks of agricultural introductions. Nature Biotechnology 15: 845-848

Broekaert WF, Terras FRG, Cammue BPA, Osborn RW (1995) Plant defensins: Novel antimicrobial peptides as components of the host defense system. Plant Physiology 108: 1353-1358

Persley GJ (1997) Global concerns and issues in biotechnology. HortScience 32: 977-979 


\section{QUESTIONS}

What could be the optimal size of a transgenic field test for resistance to a single pathogen: e.g. number of transgenic and control lines, number of individuals per line, etc?

How can efficient mechanisms be activated (esp. in the Third World) to change suspicion with transgenic plants and to accelerate legal procedures for the authorisation of field tests?

Which strategies can be adapted for using publicly acceptable target genes and avoiding selectable marker genes in vegetatively propagating plants? 